\title{
Prospects and Challenges of Using Social Sites in Higher Education
}

\author{
Afifa Khanam* \\ Uzma Quraishi $^{* *}$ \\ Shabana Kausar ${ }^{* * *}$
}

\begin{abstract}
Social networking is a virtual thread of grouping individuals. The present study has explored the prospects and challenges of using social sites in higher education. The study involved mixed method for collecting comprehensive information about the issue. A survey was conducted to randomly selected 21 university teachers and 279 university graduate and post graduate students. A significant difference was found between the perceptions of students having technological facilities in their universities and those having no facilities in higher education. Most of the participants supported the statements related to utility and possibility of using social sites for disseminating course schedules, outlines of courses, reading materials (audio, video, photofigures, print), discussing course problems, exchange of educational ideas and looking for better opportunities of admissions and career. The qualitative part of the study employed a series of focus group discussions conducted with students and teachers of graduate and post graduate level to highlight the opportunities and issues involved in disseminating instruction through social sites. Participants opined that social sites could provide flexible, versatile, attractive and creative educational activities. The major concerns came to light were publicity distraction, irregular use of social sites and extinction of specialized curricula by the universities. It was recommended that universities should take well planned initiatives with specially designed courses and generate interactive communities for class communication to ensure the use of social sites for educational purposes.
\end{abstract}

\footnotetext{
Assistant Professor Research and Evaluation Department, Lahore College

for Women University, Lahore. Email: dr.khanam.wattoo@gmail.com

** Vice Chancellor, Lahore College for Women University, Lahore.

*** $\quad$ Ph.D. Scholar, Lahore College for Women University, Lahore.
} 
Keywords: Prospects and challenges, social sites, higher education, communication

\section{Introduction}

Social network is a virtual environment where people come together to extend friendship, exchange ideas, share photofigures, videos and pictures, promote their business, fight, argue and make relations without their physical existence (Ramanigopal, Palaniappan \& Hemalathan, 2012). Social network helps people to join others having similar interests, professions, business, hobbies and ideas. People having communicational difficulties find this forum easy to access and unthreatened. Social sites enable people to control and manage information on their own pace and accord. It is difficult to come out of the spell of social sites once after getting in. These are smarter sources to learn and disseminate without boundaries of time and space and cast and creed. It encourages and supports collaborative learning approach (Boyd, Danah, Ellison \& Nicole, 2007).Now technology is an indispensable component of people's daily life and it has several social and cultural influences on their daily routines (Bateman \& Oakley, 2009).

Social sites have been recently incorporated in Higher Education setup where they are used to blend formal and informal learning. Users of social sites produce their online profiles and communicate with peers and instructors within their discipline and field. They define boundaries and select people with whom they are going to connect for specific exchange of knowledge (Boyd \& Ellison, 2007).

In higher education, Online Social Networking (OSN) is rapidly becoming prevalent around the world (Mason and Rennie, 2008, Hughes, 2009 \& Kear, 2010). OSN enables social technologies with a range of activities and it is operationalized by group of people having similar interests (Hamid, 2009). It enables users and practitioners to communicate and generate knowledge worldwide. These publicly available social technologies are now harnessed and adopted for use in higher education for supporting pedagogical approaches. Though these technologies were originally designed for non-educational and social purposes yet they are equally useful for educational dissemination (Hemmi, Bayne \& Land, 2009).

Mason and Rennie (2008) regarded social sites as attractive and influential tool of sharing educational content and building online educational communities in higher education sector. Though computer 
mediated pedagogical activities existed since 1980's, social sites were used for educational purposes in 1990s. The present trend of using social sites for educations has emerged recently with availability of massive information, growing number of users and advanced features of controlling and managing sources through specific knowledge communities.

Students can collaborate for developing social communities for sharing audio- visual and print ideas for particular objectives and outcomes both offline and online (Lockyer \& Patterson, 2008). Kennedy (2009) has described six policy issues which should be addressed in the process of learning thorough online technologies: academic integrity, equity and access to technology for all, curriculum and assessment, staff development, student learning, diversity, capacity building and information technology infrastructure. In spite of wider use of social net working for educational purposes, Kennedy (2008) cautioned that educationists should consider that some students may not be accustomed to use technologies so the material should cater needs of diverse students.

Bonk \& Graham (2006) and Garrison \& Vaughan (2008) have indicated high expectations associated with using social sites for improved instruction in higher education due to their interactivity, accessibility and content diversity for specialized disciplines. Schultz \& Sheffer (2007) and Thrall (1982) discussed that information technology has the capacity to be diffused in diverse settings but it is a gradual process which can be speeded up by rapid involvement of its users and participants.

If social sites are engaged for educational purposes, they can reduce dropout rate from tertiary education due to availability of educational material to students at flexible times, easy access, peer support and catering diverse aptitudes and interests. Brown and Adler (2008) opine that from users' point of view, online course provides student multiple choices, individual taste and personalized pace at their workplaces and homes that are far better than traditional ways of teaching. Likewise, as compared to traditional learning where curriculum is fixed and limited, subjects are diverse and infinite in online learning (Nachmias, Mioduser and Forkosh, 2008; Brown and Adler, 2008). Similar is the case with blended learning which provides multiple means to learn including face to face meetings with instructors. Hershkovitz, et al. (2007) have expressed that retention rate for students in online classes is relatively high if they are sufficiently interactive.

Gibs and Bruich (2010) suggest that social sites can be benefitted for educational purposes as all users and participants of a course or program 
can contribute in providing their own input and creative ideas to the course. It is a good collaborative source to bring together synergy of learners with their diversity and personal experiences. However people who are still not familiar with networking, need training by some administrating agency.

Pensky (2001) has thus, announced the term, 'digital divide' and distributed groups in Digital natives (generation who born after 1980, in the era of technology and social sites) and the Digital immigrants (previous generation who are struggling to understand technological tools). He remarked that different groups in the world will not be segregated now on the basis of possessions but for the use of technology. Those who have adopted technology for most of their fields of life will be considered advanced and developed.

With this perspective, universities and colleges are changing their strategies to compete $21^{\text {st }}$ Century demands. The phenomenon of world ranking has revolutionized institutions to compare them at global level. In addition, the financial deficits and economy crisis which has caused tightening of labour market has constrained institutional activities so they are forced to use technology for enhancing their accuracy, flexibility and accessibility.

MacDonald and Marsh (2005) and Roblyer et al, (2010) have discussed that social sites can be harnessed for student-centered pedagogy and effective learning. However, the expectations to technology leaning may not be realistic. Only the motivation and readiness of students can involve them in active learning and interaction. Their disposition and ability can engage them for productive leaning otherwise distractions on social sites have blurred the desired outcomes for educational purposes in higher education (Zepke \& Leach, 2010 \& Dunn, 2012).

Selwyn (2007) has enlisted several benefits of Facebook that it can be used for personalized purposes as well as for engaging groups with similar interests. It depends upon the site manager who organizes and updates the material and contents in order to enhance its usability. It is a good source of taking feedback from people worldwide.

Panckhurst (2008) argues that social sites (facebook, twitter, tumblr etc) can be used directly for higher education by putting specific and focused tasks within a planned and integrated course outline to give students autonomy. Lave and Wenger (1991) have suggested the role of instructor as facilitator or guide to promote 'community of practice' for such educational forums. 
In Zimbabwe, according to Ngonidzashe (2013), some universities are using social sites for tertiary education despite threats of securities and privacy. He identifies that research on the use of social sites has been conducted in developed countries in several areas including academic, administrative, promotions and dissemination of knowledge and support areas but in developing countries, it is rare and insufficient to explore the possibilities and opportunities of using social sites for higher education. Social Sites are used in both dimensions of education for developing interest in students and for developing new pedagogies on the part of innovative instructors. However, he found problems of security, unproductive use of site and unethical behaviour practiced by university students.

Fogel \& Nehmad (2009) found in their study that 78\% students at tertiary level were using facebook for educational purposes in one way or the other while Ellison, et al, (2008) declared that 95.5\% of higher education students were using social sites in their daily life. Ellison (2006) \& Grossman (2010) commented that such concentrated presence of students is not surprising even the site started in 2004 because all social sites got popular with the same speed.

Previous researches like Kennedy (2009), Hemmi (2009) \& Jones (2005) who studied general use of ICT and social technologies by youth found that adaptation of social technologies for educational purposes was not a straight forward process. However, these technologies were used for educational purposes with a certain degree of success.

Social networks though contain information of every type, however, all is fragmented and disconnected. Once entering into the site and preparing basic profile, some may sit back and think what next to do. Thus, for educational purpose, it needs to be organized, specified and sequenced for a specific category of content whether it is audio-visual or in print form. Well planned courses are scarce for engaging students in educational activities and usually are not accredited.

Informally, social sites are already in use of several teachers and students. They use them for class discussions, quizzes, posting assignments and tests which are offered casually for the convenience of distant students. These sites are also used for the promotion of personal contributions like comments, essays, articles and tasks assigned outside the class room. Some institutions use these sites for parent teacher communication and feedback. They promote their achievements, events and celebrations. It has made easy for parents to raise their voices to the administration without their physical presentation. 
The present study is focused on the use of social sites for educational purposes and the opportunities it can offer for students of higher education in Pakistan. It addresses the gap of theoretical underpinnings of technological approaches and their realistic use in the field and challenges that may hinder its effective use. The literature above presents a holistic picture of the usability and popularity of social sites in students and to establish a background why should its prospects, scope, and feasibility be visualized for incorporating it for educational purposes. For the dire need of raising forums of higher education in the country and social sites being one of the wider opportunity to achieve the goal, the study exclusively intends to investigate teachers' and students' perceptions using social sites regarding its educational dimensions and the challenges they may face for imparting education through these technologies.

\section{Statement of the problem}

The literature and discussion above indicates the need of further exploration of the phenomenon so the researchers intended to study the prospects and challenges of using social sites in higher education.

\section{Objectives of the study}

1. To investigate the expectations and feelings of teachers and students for using social sites in public and private universities at higher education.

2. To explore the challenges and prospects perceived by teachers and students for extracting optimum advantages of using social sites in higher education

3. To put effective recommendations for appropriate adaptation of social sites in higher education on the basis of study findings.

\section{Research Questions}

1. What are the prospects of using social sites in higher education for enhancing equity and equality of opportunities in Pakistan?

2. How are the resources of social sites accessible to the students?

3. How, why and what are the possibilities of using social sites for learning enhancement at higher education in Pakistan? 
4. How sites for higher education can present socially-inclusive models for deprived students?

5. What are the obstacles or challenges to harness social sites for educational purposes during practice?

\section{Hypotheses}

\section{Null Hypotheses}

$\mathrm{H}_{01}$ : The opinions of students from different universities are not significantly different about use of social sites in higher education.

$\mathrm{H}_{02}$ : The opinions of teachers from different universities are not significantly different about use of social sites in higher education.

\section{Methodology}

The research involved both quantitative and qualitative paradigms for investigation of the phenomenon. The mix method was used to highlight teachers and students' perceptions about use of social sites for higher education. It was intended to explore the opportunities regarding existence of skill level, resources and feasibility of using social sites for educational purposes. The survey method was used to collect data about teachers and students' perceptions from four universities of district Lahore. A series of focus group discussion among teachers and students of graduate and post graduate level was conducted to collect qualitative data about the prospects and challenges of engaging social media technologies for higher education.

\section{Population}

All students and teachers of graduate and post graduate level in District Lahore were taken as the population of the study.

\section{Sample}

The sample of the study was consisted of twenty one university teachers and 279 graduate and post graduate students at four universities of district Lahore; University of the Punjab, Lahore, University of Management and Technology, Lahore College for Women University, Lahore and Beacon House National University, Lahore as per researcher's accessibility and availability of convenient transport. The 
sample within universities was selected through random sampling technique.

\section{Instrument}

The researchers prepared two questionnaires for students and teachers separately on five point Liker scale with six factors mentioned below:

- Awareness about use of social sites and their scope in education

- Possible role of policy making agencies in determining scope of social media technologies for universities and organizations

- Nature of content and activities introduced through social sites

- Advantages and disadvantages of social sites for using educational purposes

- Prospects and challenges of using social media for promoting higher education

- Practices and frequency of using social media in daily routine

The instrument was validated through pilot testing and expert opinion. The reliability of the instrument was calculated by split half method and the value of correlation coefficient was, $r=.67$. A series of questions were developed for focus group discussion encompassing research questions.

\section{Administration of the instrument}

The questionnaires were personally distributed by the researchers while they were uploaded on Facebook and email for general response also. The focus group discussion was conducted with the help of concerned department's administrators. Each of the session was held with eight to ten participants willing to participate and the discussion continued for approximately one hour. Total eight sessions were held cumulatively.

\section{Analysis of the data}

The score obtained by survey questionnaire was analyzed by descriptive as well as inferential statistics. The frequency means of all groups were calculated and different groups like, male-female, studentsteachers; public-private sector, graduate-post graduate etc. were 
presented in figures. The focus group discussion was recorded and transcribed by the researchers. Interpretation of themes and meanings were developed for final conclusion.

\section{Results}

\section{Quantitative data analysis}

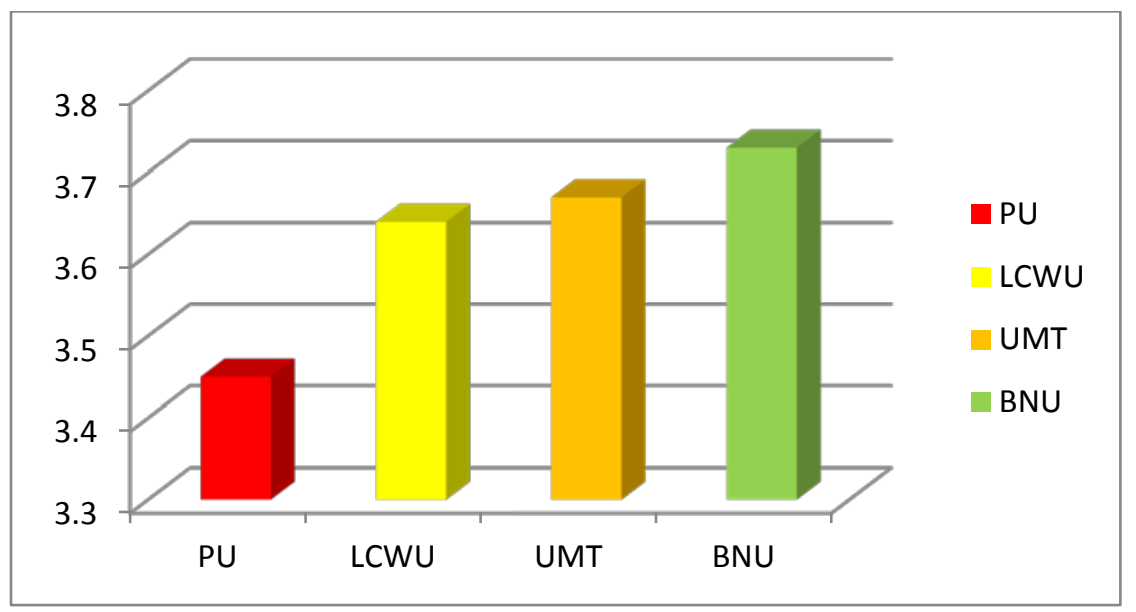

Figure.1. A comparative presentation of four public and private universities for using social sites in higher education

The above figure shows that almost all of respondents agreed about the use of social sites in higher education. The students of different universities like of BNU with $(\mathrm{M}=3.73)$, UMT $(\mathrm{M}=3.66)$ and LCWU $(M=3.64)$ and PU $(M=3.45)$ were agreed about the use of social sites in higher education. It is visible that students at public universities are less interested in using social sites in higher education as compared to that of private universities. 


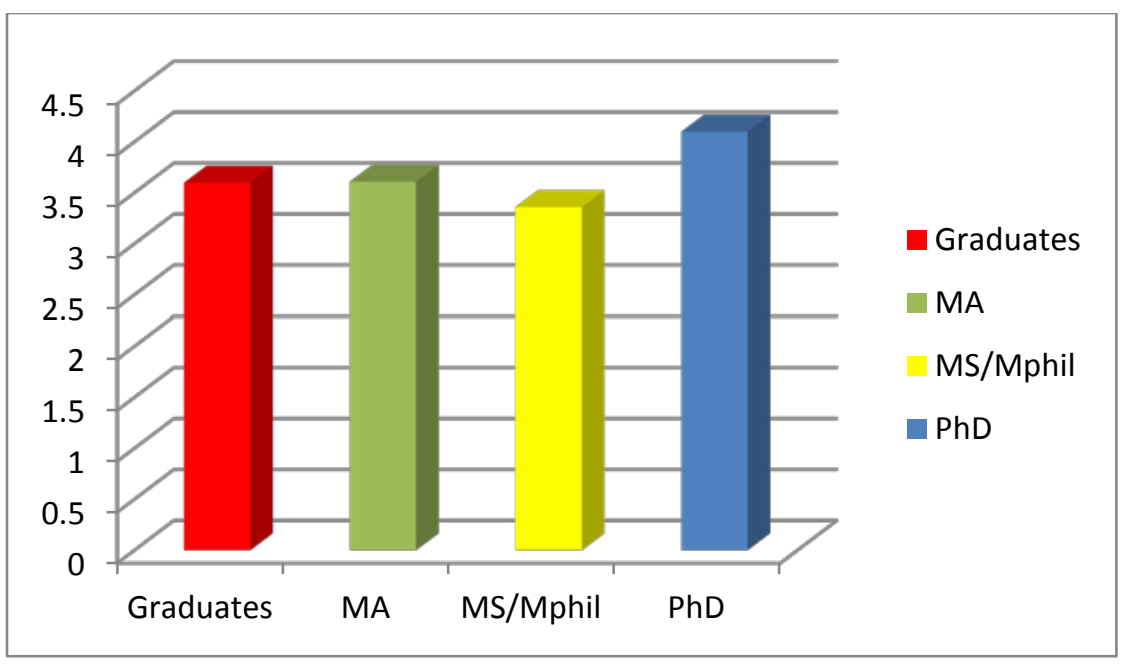

Figure. 2. Comparison of opinions of students from different programs at all universities about using social sites in Higher Education

The above figure shows that almost all of the students of graduate and post graduate levels agreed about the use of social sites. The participants of different qualification of P.hD with $(\mathrm{M}=4.1)$, MS/M.phil $(M=3.36), M . A(M=3.60)$ and Graduates $(M=3.60)$ were agreed about the use of social sites in higher education.



Figure.3. Comparisons of opinions of students from different subjects at all universities about using social sites in Higher Education 
The above figure mentions that almost all of the students from different subjects were agreed about the use of social sites. The students of different subjects that of sciences with $(\mathrm{M}=3.47)$ and social sciences with $(M=3.54)$ were agreed to use social sciences in higher education.

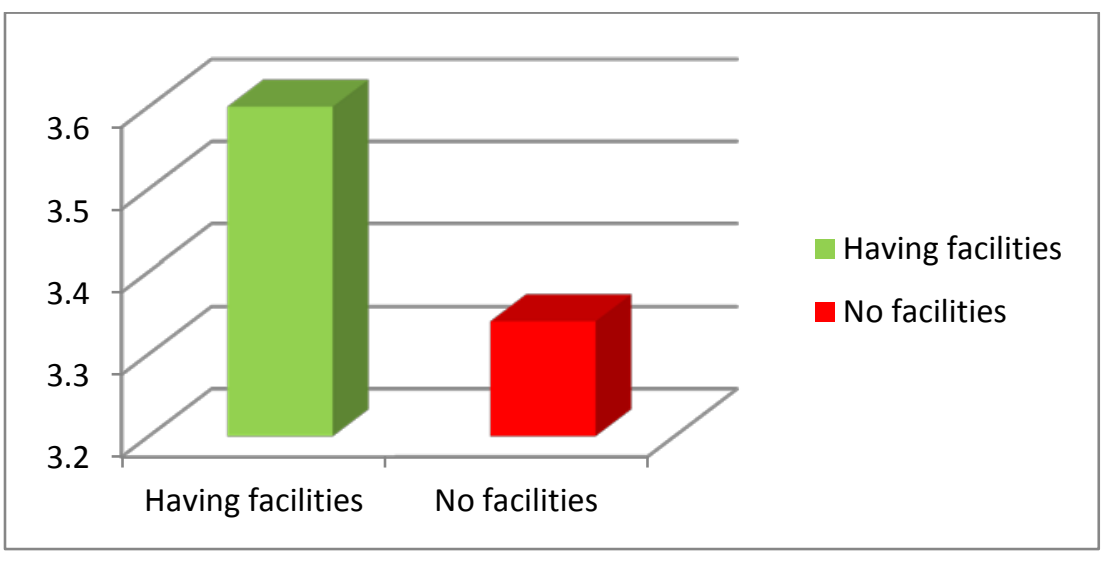

Figure.4. Comparison of opinions of students having or having not ICT facilities at all universities about using social sites in Higher Education

The above figure shows that almost all of the students agreed about the use of social sites in higher education. The students having ICT facilities and those having no facilities with $(\mathrm{M}=3.60)$ and $(\mathrm{M}=3.36)$ respectively were agreed to use social sites in higher education.

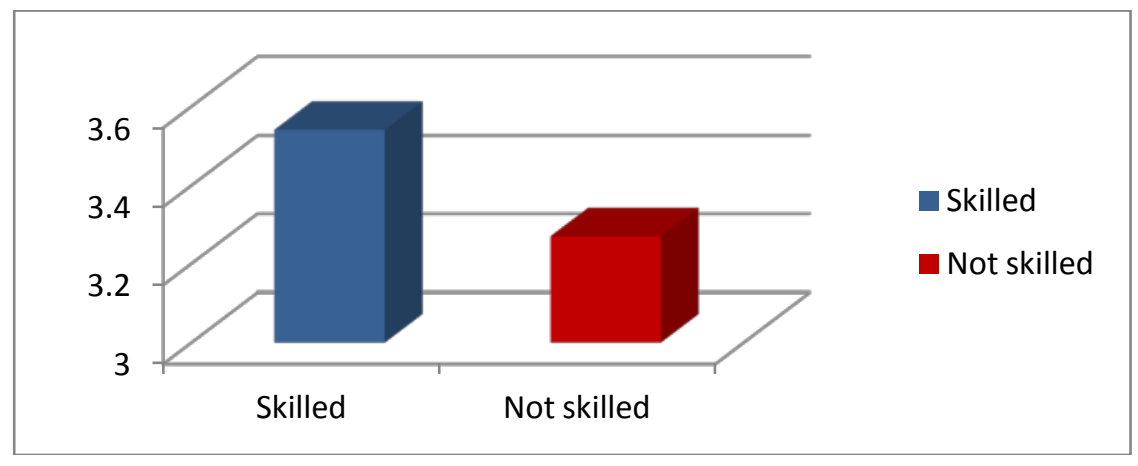

Figure.5 Comparison of opinions of students having or having not ICT skills at all universities about using social sites in Higher Education 
The above figure shows that almost all of the students were agreed about the use of social sites in education. The students of different universities having ICT skills with $(\mathrm{M}=3.53)$ and those who had not ICT skills with $(\mathrm{M}=3.27)$ supported the idea of using social sites in higher education.

Table 1

ANOVA calculation for teachers from four universities about using social sites in higher education

\begin{tabular}{llllll}
\hline Score & & & & & \\
& Sum of Squares & df & Mean Square & F & Sig. \\
\hline Between Groups & .481 & 3 & .160 & .867 & .477 \\
Within Groups & 3.143 & 17 & .185 & & \\
Total & 3.624 & 20 & & & \\
\hline
\end{tabular}

A one-way ANOVA was applied to test the significant difference among the opinions of teachers for the prospects and challenges of social site usage in higher education. The scores obtained by the teachers of different universities were not significantly different with $\mathrm{F}(3,17)=$ $.867, \mathrm{p}=.477$. The results declared that the hypothesis 1 "there is no significant difference among teachers of different institutes like PU, LCWU, UMT and BNU was accepted.” All of the teachers from different universities were unanimously of the opinion that social sites could be used for higher education as a supporting tool.

Table 2

ANOVA Calculation for students of four universities about using social sites in higher education

\begin{tabular}{llllll}
\hline Scores & Sum of Squares & Df & Mean Square & F & Sig. \\
\hline Between Groups & 2.891 & 3 & .964 & 5.277 & .001 \\
Within Groups & 50.229 & 275 & .183 & & \\
Total & 53.121 & 278 & & & \\
\hline
\end{tabular}

A one-way ANOVA was applied to find the significant difference among the opinions of scores of students of all universities. The scores obtained revealed that there was a significant difference with $\mathrm{F}(3,275)=$ $5.277, \mathrm{p}=.001$ among the students of different universities. The results declared that the hypothesis 2 "there is no significant difference among the opinion of students of different institutions like PU, LCWU, UMT and BNU was rejected." The students of public universities were more 
reluctant to admit role of social sites in higher education as compare to those of private universities.

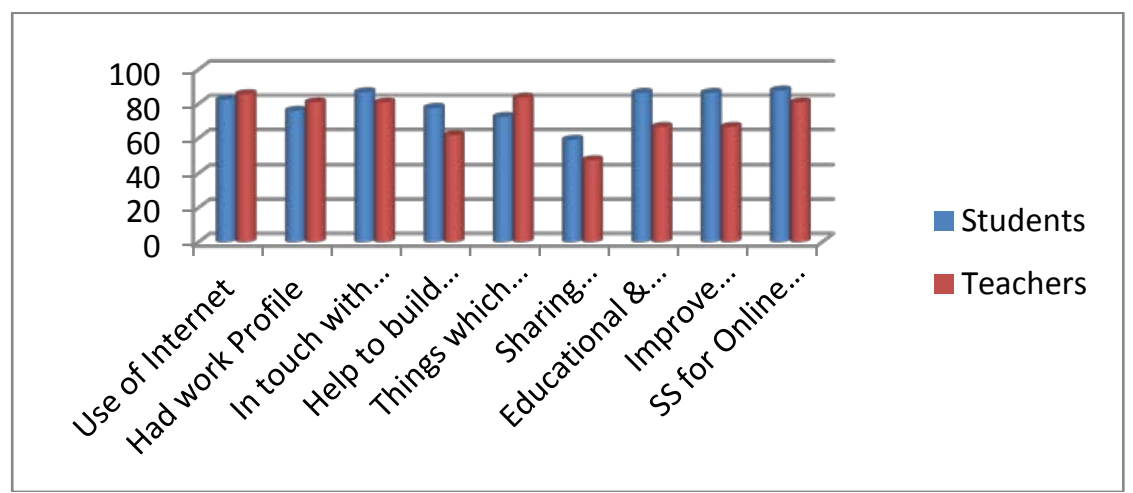

Figure.6. Use of social sites for informal educational discussions

The above figure shows that all teachers and students from all universities informally use social sites for sharing their profile, keeping in touch with class fellows, build social relations, sharing comments, exchanging educational material, improving information and quick linkages with other students and professionals. They also prefer social sites for sharing ideas which they could not share face to face. However, cumulatively, students seem more active in using social sites for informal use while teachers preferred to use this media for educational purposes and foreign linkages.

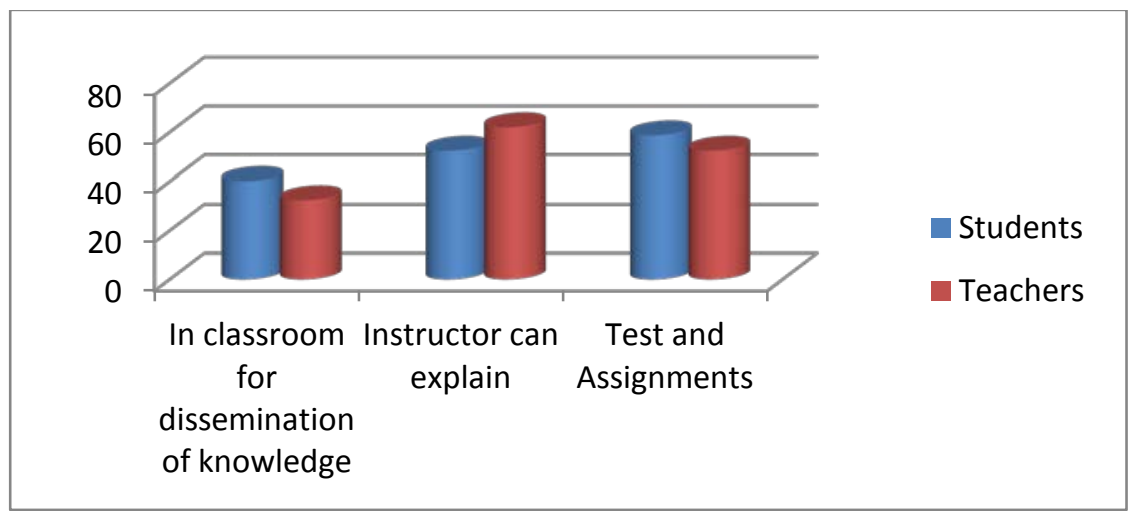

Figure.7. Use of social sites for classroom activities 
The figure above reveals that students are more interested in the use of social sites for classroom activities like dissemination of daily lectures or taking tests and assignments. However, teachers are more interested in classroom explanations or sending reading material through social sites.

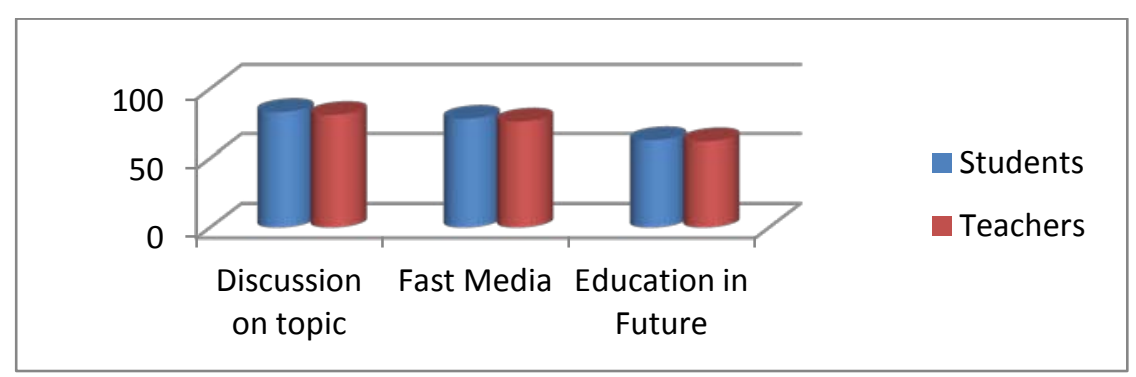

Figure.8. Use of social sites for better accessibility of learning material

The figure above shows that almost all teachers and students are of opinion that social sites can be good source of subject discussions and education in future. Because, with the passage of time, social sites are becoming more and more interactive and well equipped. They also agreed that social sites are quick and timely to disseminate information regarding courses.

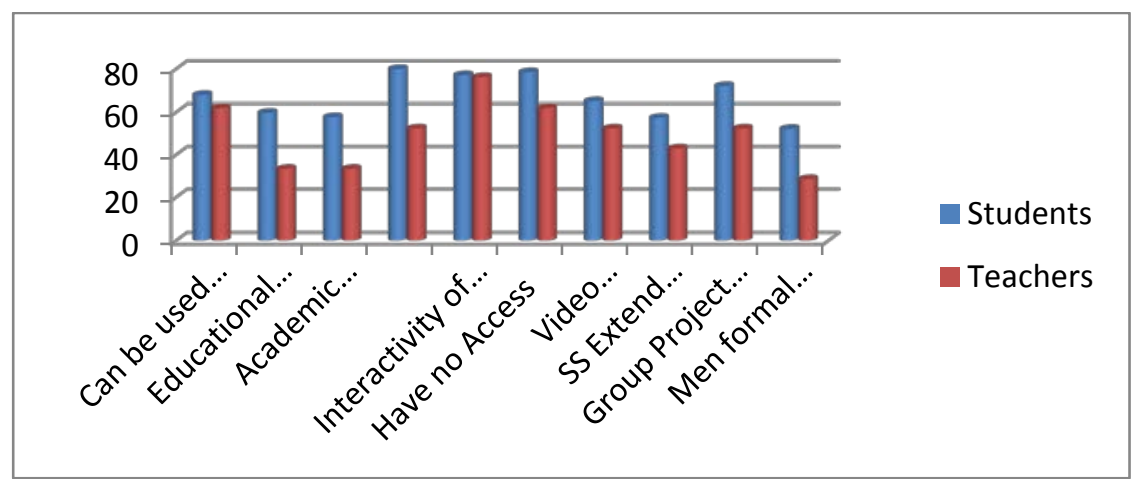

Figure.9. Use of social sites in teaching learning activities

The table above declares that students are far more convinced than teachers of advantages of social sites in teaching learning activates like enhancing students educational capacity, academic performance, increasing creativity and interactivity. Students are more interested in 
group project learning and learning through cell phones. However, both teachers and students have supported interactivity of these sites for quick communication.

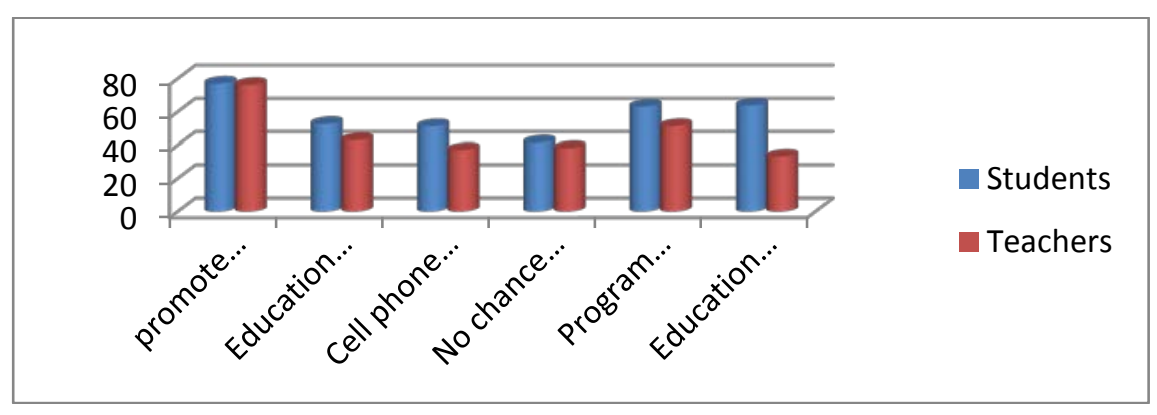

Figure.10. Use of social sites for organizational propagation

The figure 10 above shows that students are more aware than teachers of using social sites for propagation of organizations. They agreed that universities can advertise their programs to be accessed through cell phones. They can advertise their course outlines, admissions and other online activities through social sites.

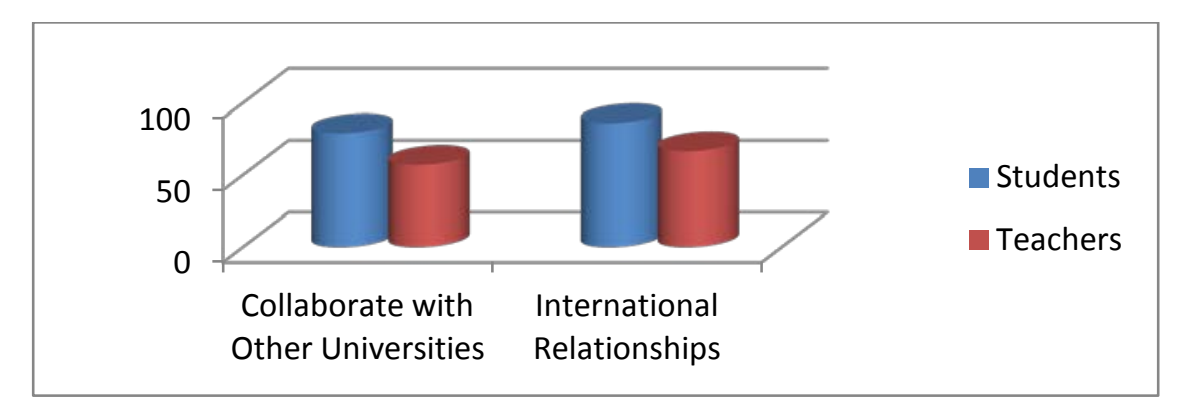

Figure.11. Use of social sites for career opportunities

The figure above declares that students are more interested in seeking collaborations for national and international professionals as compared to their teachers. They take it as a good source of hunting jobs and careers. 


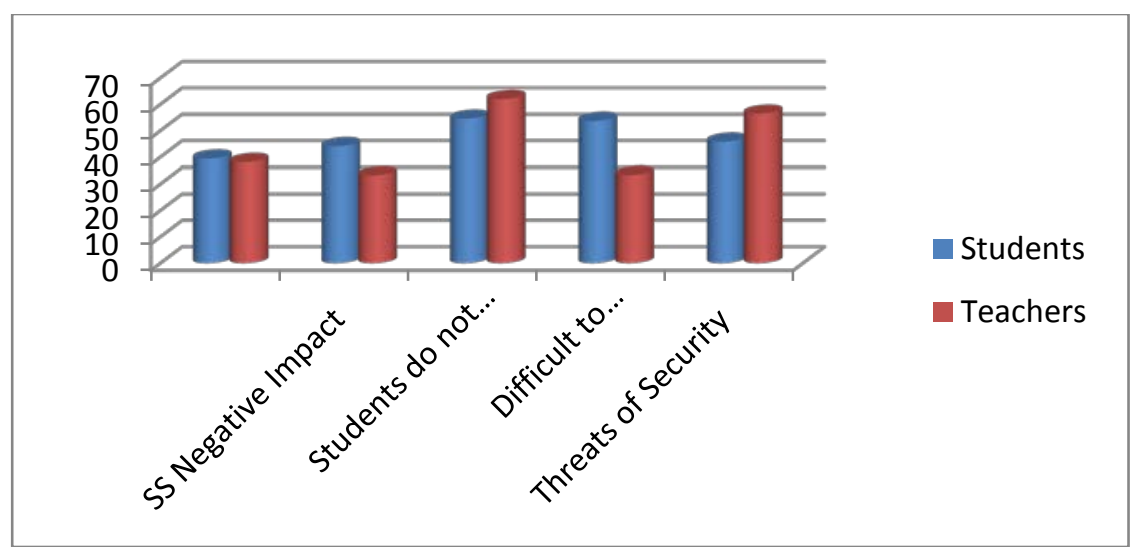

Figure.12. Challenges of using social sites in higher education

All students and teachers are agreed that using social sites for educational purposes at higher levels may cause challenges like distracting from education, difficulty in regularizing educational programs and controlling individual security. They also were in the favor that using social sites may cause absence of seriousness on the part of students and can persuade them towards negative activities.

\section{Qualitative data analysis}

Q.1-What are the prospects of using social sites in higher education for enhancing equity and equality of opportunities in Pakistan?

While discussing the first question, the teachers and students were very much excited about the opportunities of social sites for solving educational problems. Majority of the respondents opined that different courses and diplomas can be introduced through social sites but several challenges can be there for proper registration of students, educational program's authenticity, accreditation, or acceptability etc. They suggested that social sites, if not offer proper program or degree, can be exploited for assisting like dissemination of learning material, relevant pictures, videos, or other helping material. Students admitted that most of the students had social groups to share course activities with classmates. They said that, "teaching is not such traditional as a few years before. It is more flexible and learner centered now." The students said that, "teaching is not passive now. Some respondents mentioned that social sites (SS) were useful for self-studies and for active interactions with 
their teachers. A few students said that SS had facilitated them to get admission to refresher courses in any university. Majority of the students opined that social sites are need of the university students. The teachers were unanimously of the opinion that there is need of planning how social sites can be used as a part of the course. They were reluctant to think that a full fledge course could be offered through the social sites. However, students expressed that they took help for their researches, communicating national and international resource persons, sharing their information with friends and professionals. They said that mostly they were using SS informally for sending pictures, videos and documents to other fellows. One of the student said that, "social sites are quite resourceful because we know about studies abroad and job opportunities from social sites. It is quick and timely."

Q. 2- How are the resources of social sites accessible to the students?

The respondents opined that SS are accessible for most of the students through computers or cellphones. So if there are some educational programs which could be delivered through social sites, "more students could have access because a number of youngsters are using SS." Teachers expressed that carefully designed programs are possible to deliver to individuals who have no access to universities because they are on job or live away from the institutions. It can add flexibility, self-learning, motivation, interest and individual pace. One student said, "It can help collaborative learning." Some students suggested that adult literacy programs and community awareness campaigns by students and teachers can help to expand educational resources to the society.

Q.3-How, why and what are the possibilities of using social sites for learning enhancement at higher education in Pakistan?

All students and teachers unanimously said that more or less all university students can have access to SS through smart cell phones if they don't have computers.

Q.4- How sites for higher education can present socially-inclusive models for deprived students?

Members of focus groups raised loud voices for highlighting opportunities of using social sites with socially-inclusive models. They expressed that students of all casts and creeds, having any economic status and deprivation can avail educational programs through social 
sites because these have wider scope to hold learning material if courses are prepared with specific techniques and well organized by universities. Q.5- What are the obstacles or challenges to harness social sites for educational purposes during practice?

Respondents told that some students used Facebook or other social sites for negative purposes, create fake accounts and violate others' privacy. They complained that students spent unnecessary time on social sites. Regarding challenges, respondents said that students staying in remote areas have no accessibility to skill of using social sites and if there is net, it is out of order most of the time and for this reason they could not attend classes regularly. They could not find resource books for such skills also. Several students mentioned that universities had no labs and trainings for such skills and they did not provide organizational support to students in this regard.

Finally, the respondents strongly recommended use of cell phones for disseminating knowledge and they said that if it can be used to share personal experiences and information, students can share their personal photos, videos and comments, they can also share educational material and information. They suggested that organizations should promote such programs and expected that these programs would become popular among students.

\section{Discussion}

The discussion has been sorted out in two dimensions according to the topic of the study:

\section{Prospects}

Purpose of the study was to find out prospects and challenges of using social sites in Education. The study gathered both quantitative and qualitative data. The findings and conclusion above declare that social sites have great potential for dissemination of education in Pakistan. Using social sites is no more a fiction for our country. People are already engaged in using social sites for several purposes. The present study has supported several recent researches claiming the opportunities of using social sites for educational purposes at tertiary level, like; Ramani, Palaniappan \& Hemalathan (2012), Bateman \& Oakley (2009) Boyd \& Ellison (2007) who have mentioned interactive properties of social sites for dissemination of knowledge. The study found positive perceptions of 
teachers and students about use of social sites within and out of class activities like Hemmi, Bayne \& Land (2009), MacDonald and Marsh (2005), Roblyer et al, (2010), Schultz \& Sheffer (2007) and Thrall (1982) who indicated possibilities of social networks for making 'learning communities' and imparting education through worldwide knowledge access networks. The findings of the study were consistent with the Panckhurst (2008) and Selwyn (2007) who suggested effective use of social sites for educational purposes and disseminating different programs for deprived groups of people in the country.

\section{Challenges}

Many challenges have been found for using social sites for education during the research because some respondents said that they had not been provided with the proper opportunities of using social sites for educational purposes. People from academia faced problems of security, content organization, lack of institutional support and possibilities of frequent distractions with social sites. Such challenges have been indicated by Ngonidzashe (2013) in Zimbabway where students faced security problems and were afraid of distraction caused by social sites. Some teachers and students said that the social sites had imparted negative impact on users because they use SS for long time without any restriction. The study brought to light some challenges that were also found by Kennedy (2009), Hemmi (2009) \& Jones (2005) who commented that using social sites for educational programs is not an easy task. Teachers and students in Pakistani universities opined that only well-organized syllabi by universities and constant monitoring by site managers can make educational programs successful.

\section{Recommendations}

The study has revealed great potential of using social sites in higher education. Majority of teachers and students have positively commented on the opportunities of engaging social networks for dissemination and promotion of educational programs, reading material, audio-visual links and other program managing tasks. On the basis of findings, the researcher has presented following recommendations:

- Government's policy about laptop distribution may be more helpful if students from deprived areas are given preferences. 
- Teachers at universities should be provided trainings for using social sites for their educational tasks and preparing needful modules.

- Universities should take initiatives to offer programs through social sites through well-organized teams of experts.

- The government should make policies for providing internet facilities to backward areas.

- There should be seminars and conferences for dissemination of knowledge through social sites.

- Short term courses could be started for pilot testing and then deficiencies of the system can be removed

- Using social sites should be pilot tested for short term diplomas and certificates first.

- Universities teachers should create learning communities, discussion forums and reading clubs for familiarizing students with using social sites for educational purposes.

- Teachers should make their class accounts for getting rapid feedback from students.

- Social site accounts should be created for engaging formal system students to share classroom schedules, announcements, quizzes etc.

- Universities should offer social sites desks for students to take timely and interactive information about their programs.

- Specific model of cell phones could be introduced at reduced prices within fee structure of university for smooth dissemination of content material and information

- Universities can introduce specific models of cell phones on less prices for university students

- Universities need planning for future modes of education at their earliest and share global experiences of developed countries for using social sites for education.

Universities should plan activities on global standards and get access through moocs and other open access sources.

\section{Conclusion}

Cumulatively, analyzing the results of both qualitative and quantities data, it was concluded that using social sites for higher education in future has vast potential.

Majority of university teachers and students were using social sites for making their profiles, sharing ideas, reading material, relevant 
pictures, videos and audios. They were quite familiar with the technological procedures to maintain their sites and were updating them regularly.

They were collectively of the opinion that social sites may be successful source of disseminating educational programs. All other managerial tasks related to dissemination of programs like admissions, advertisements, schedules, time tables, date sheets were already in practice either formally or informally by different institutes.

Majority of the teachers either they were from public or private universities, commented that social sites are a big source for international linkages, career abroad, video conferences, rapid sharing of learning material like audio, visual files. They were convinced that social sites were interactive source of discussions and chat. So they favored the idea of using social sites in future for higher education.

In focused group discussions, people from academia said that if social sites can be used for interacting and sharing all types of material, it could be perfectly used for educational purposes. However, they commented that presently universities are not considering their importance for educational programs. They need well developed modules/lessons to be delivered by social media. Only trained teachers can prepare such material, therefore, teachers should be trained first for managing sites successfully. They informed that most of the students use these sites for social interaction for hours and if it will be used for education, students will be more interested.

The university teachers also used social sites for informal group discussions, sending assignments, sharing reading materials, presentation files and videos etc. They had their existence in social groups of their teachers and university administrators.

It was found that teachers from public universities were less interested in use of social sites for educational purposes which declared their less exposure to technology and less involvement in technological practices regarding social sites. However, students from all four universities almost equally supported the idea and mentioned the potentials of social sites for providing equality and equity to all students present in different areas of the country. They found it attractive and engaging.

The students from the biggest public university were least interested in using social sites for educational purposes. All personnel relating academia mentioned the challenges one can face using social sites for educational purposes as: security threat, advertisement distraction, sharing irrelevant material, accessibility issues during online sessions 
and lack of infrastructure in universities. They complained that universities were not exploiting the features of social sites for educational programs. Further they pointed out that all students may not have equipment like laptops, cellphones or internet connection to avail such programs. The problems of registration of students, educational program's authenticity, accreditation and acceptability were also raised during the discussion.

The universities were not currently offering educational programs on social sites because they have fewer human and material resources to prepare, update and maintain the sites regularly. It was found that students were cumulatively more aware of the use of social sites as compared to their teachers. It was probably due to their more engagement in social sites and spending more time on informal sharing and maintaining sites. Finally, the study recommends that universities should plan and develop educational programs in Pakistan for coping future innovations in the world and prefer technological benchmarks for effective and productive use of social sites for offering higher education programs. It may prove a big source for delivery of higher education to the less advantaged groups of students in the country.

\section{References}

Bateman, D., \& Oakley, C. (2009). The Classmate PC 1:1 eLearning project in Australia. Melbourne: Deakin University in partnership with Intel Australia Pty Ltd.

Bonk, C.J., \& Graham, C.R. (2006). The handbook of blended learning environments: Global perspectives, local designs. San Francisco: Jossey-Bass/Pfeiffer.

Boyd, D. (2006). Friends, fraudsters, and My Space Top 8: Writing community into being on social network sites. First Monday, 11(12).

Boyd, D. M \& Ellison, N. B (2007) Social network sites: Definition, history, and scholarship. Journal of Computer-Mediated Communication, 13(1), article 11. http://jcmc.indiana.edu/vol13/issue1/boyd.ellison.html 39573

Brown, J.S. and Adler, R.P. (2008). Minds on Fire: Open education, the long tail, and learning 2.0. Educause review, vol. 43, 1, pp. 16-20. Available at http://www.educause.edu/ero/article/minds-fire-open-education-long-tailand-learning-20 (accessed 3 February 2016 ). 
Dunn, L. (2012). Why it's time to start BOYD in your school on edudemic. http://edudemic.com/2012/12/why -its-time-to-start-byod-in-your-school/ (last accessed on 3/02/2016).

Ellison, N., Steinfeld, C., \& Lampe, C. (2006). Spatially bounded online social networks and social capital: The role of Facebook. Paper presented at the Annual conference of the International Communication Association, Dresden, Germany.

Ellison, N., Steinfield, C., \& Lampe, C. (2007). The benefits of Facebook "friends:" Social capital and college students' use of online social network sites. Journal of Computer-Mediated Communication, 12, 1143-1168.

Fogel, J., \& Nehmad, E. (2009). Internet social network communities: Risk taking, trust, and privacy concerns. Computers in Human Behaviour, 25(1), 153-160.

Garrison, D. \& Vaughan, N. (2008). Blended learning in higher education: Framework, principles, and guidelines. San Francisco, CA: John Wiley \& Sons.

Gibs, J., \& Bruich, S. (2010). Advertising Effectiveness: Understanding the Value of a Social Media Impression. US: The Nielsen Company.

Grossman, L. (2010). Person of the year 2010: Mark Zuckerberg. Time Magazine.

http://www.time.com/time/specials/packages/article/0,28804,2036683_2037 183_2037185,00.html

Hamid, S., Chang, S., \& Kurnia, S. (2009). Identifying the Use of Online Social Networking (OSN) in Higher Education. Paper presented at the In Same places, different spaces, Ascilite Auckland 2009.

Hemmi, A., Bayne, S., \& Land, R. (2009). The appropriation and repurposing of social technologies in higher education. Journal of Computer Assisted Learning,25(1), 19-30. 10.1111/j.1365-2729.2008.00306.x

Herhskovitz, A., \& Nachmias, R. (in press). Online Persistence in Higher Education Web-supported Courses. To appear in The Internet and Higher Education.

Hughes, A. (2009). Higher education in a Web 2.0 world: Report of an Independent Committee of Inquiry into the impact on higher education of 
students' widespread use of Web 2.0 technologies. UK.

Jones, M. C., \& Twidale, M. B. (2005). What's in a name? Exploring the connections between abstraction and appropriation. [text]. International reports on socio-informatics 2(2), 43-47.

Kear, K., Woodthorpe, J., Robertson, S., \& Hutchison, M. (2010). From forums to wikis: Perspectives on tools for collaboration. Internet and Higher Education, 13, 218-225.

Kennedy , G., Dalgarno, B., Bennet, S., Gray, K., Waycott, J., Judd, T., et al. (2009). Educating the Net Generation: A Handbook of Findings for Practice and Policy. Carlifornia, USA: Creative Commons.

Kennedy, G., Judd, T., Churchward, A., Gray, K., \& Krause, K. (2008). First Year Students' Experiences With Technology: Are They Really Digital Natives? Australasian Journal of Educational Technology (AJET 24), 24(1), 108-122.

Lave, J. \& Wenger, E. (1991). Situated learning: Legitimate Peripheral Participation. Cambridge: Cambridge University Press. ISBN 0-52142374-0.; first published in 1990 as Institute for Research on Learning report 90-0013

Lockyer, L., \& Patterson, J. (2008). Integrating Social Networking Technologies In Education: A Case Study Of A Formal Learning Environment. Paper presented at the Eighth IEEE International Conference on Advanced Learning Technologies.

MacDonald, R. \& Marsh, J. (2005). Disconnected Youth?: Growing up in Britain's poor neighbourhoods. Basingstoke: Palgrave Macmillan. Journal of Social Policy, Vol. 36, Issue, 02.

Mason, R., \& Rennie, F. (2008). E-Learning and social network handbook: Resources for higher education. Madison Ave, New York: Routledge.

Nachmias, R., Mioduser, D., \& Forkosh-uch, A. (2008). Innovative Pedagogical Practices Using Technology: The Curriculum Perspective. In Knezek, J. and Voogt, J. (eds.). International Handbook of Information Technology in Education. NY: Springer, 163-179.

Ngonidzashe, Z. (2013). Challenges and perceptions towards use of social media in higher education in Zimbabwe: a learners' perspective. International Journal of Scientific \& Engineering Research, Volume 4, Issue 5.pp. 242249 
Panckhurst, R. \& Marsh, D. (2008).Communities of Practice. Moving from Institutional Platforms to the Open Web as a Platform", 4-5 February 2008, Paris, 6 pages.

Prensky, M.(2001). Digital Natives, Digital Immigrants. On the Horizon. MCB University Press, Vol. 95

Ramanigopal, C., Palaniappan, G., \& Hemalatha, N. (2012). Social networking: Problems and prospects of the knowledge society. International Journal of Research in Management, Economics and Commerce, 1(2), 116-129.

Roblyer, M.D., McDaniel, M., Webb, M., Herman, J., \& Witty, J.W. (2010). Findings on Facebook in higher education: A comparison of college faculty and student uses and perceptions of social networking sites. Internet and Higher Education, 13, 134-140.

Schultz, B., \& Sheffer, M.L. (2007). Sports journalists who blog cling to traditional values. Newspaper Research Journal, 28(4), 62-76.

Selwyn, N. (2007). Citizenship, technology and learning - a review of recent literature: Bristol: Futurelab.

Selwyn. N, (2012). Social Media in Higher Education. The Europa World of Learning 2012. Routledge 2011, all righr reserved. www.worldoflearning.com

Thrall, C.A. (1982). The conservative use of modern household technology. Technology and Culture, 23(2), 175-194.

Zepke, N. \& Leach, L. (2010). Improving student engagement: Ten proposals for action. Active Learning in Higher Education. 11: pp.167-177.

Received on: July 18, 2016

Revised on: November 28, 2016

Accepted on: December 28, 2016 